\title{
Meeting the tree people
}

\author{
Alex Wamafma
}

I was very surprised to see people around Digul living in extremely high tree houses. There could be between 50 to 60 people in a single house. They were generally all from one clan. And in their understanding, yes, a village was a house. So if they said that someone was from the same village, it meant that the person was from the same house in the treetops.

Dealing with them was my first job as a civil servant after completing my education at OSIBA. My position then was ter beschikking ('at the disposal of'), meaning that I was directly seconded to the HPB. So I could be given orders by the HPB, but not by the district head. If, for example, the district head needed me, he had to make his request directly to the HPB. I started with the rank of candidaat bestuurs assistent (CBA, assistant administrator candidate).

My first task, which I felt was a major challenge at the time, was to get the people who lived in tree houses to be willing to come down and establish villages together like usual villages. It really was a bit difficult initially, but we managed to convince them because we used contact articles such as axes, machetes, knives and fishing tools. Finally they were interested and willing to go along with our plans.

Actually, they had once lived together, but tribal warfare made them become afraid and isolate themselves in their own clan groups. And once they managed to live together in one village, we proposed to the Department of Education and Culture to send teachers there. Or we asked the Catholic and Protestant church schooling foundations to send teachers if the places where the people resided were within their work areas.

Now I hear that these villages still exist, meaning that they do not want to be separated again. I last heard in 1994 from Reverend van der Velde of the Gereformeerde Vrijgemaakte Zending (Protestant Reform 
Church) that the villages we established were still there and doing fine. He was formerly a pastor but later became a reverend. When I served in Digul and later, in Mappi, he also worked there.

The locations chosen to be turned into villages were places that were not far from the sago forest areas. The inhabitants of the Digul area indeed lived on sago. They ate sago and sago caterpillar, fish, pork and cassowary meat, which were all easily obtained in the vicinity. When the higher ground went dry, they moved to another place. They just revolved around the sago areas. So they were never far from there when you called on them, unlike the people in the mountains, who were remote and hard to find.

\section{TRANSFERRED EVERY THREE MONTHS}

Before I went to the school for administrators, or OSIBA, there was a list that was circulated through the principals of every Jongens Vervolgschool (JVVS, follow-up school for boys) throughout Papua. On that list the teachers were asked to put the names of prospective students for OSIBA. And through a process of selection or choice, I was finally sent there together with six other students. So we were seven in all. I was a graduate of JVVS Korido, Biak Numfor.

While I attended OSIBA travel costs at the beginning of and during my education were totally covered by the Dutch government, along with the costs of school supplies, return travel on annual vacations (school holidays), practice fees for one year, and the cost of returning after going through the final exams. So OSIBA was the most expensive of all the schools at that time, that is, from 1950 through 1958, even until 1960. I entered OSIBA in 1953, finished in 1958. My friends from that period who are still around today are Faidiban and Ismaël Bauw, and the others are no longer in Jayapura, those who are under me are Boray as well as Luther Saroy. OSIBA was the continuation of the school formerly known as Bestuurs Opleiding School (BOS, Administrative Training School). BOS was a sort of accelerated course.

BOS received graduates from the JVVS, as well as civil servants who had been assigned learning tasks, such as Frans Kaisiepo, Eliezer Bonay and Filemon Jufuway. They were government employees or, as they were then called, assistant administrators who were ongediplomeerd (without a 
diploma). Through a three-year course of study they received a diploma. JVVS graduates had to attend OSIBA for five years. During the first two years we had basic instruction in Dutch language, English language, arithmetic, algebra, history, and so on. But in the second phase we had to practice. My friend Lucas Mahuze and I did our practice in Manokwari.

Lucas Mahuze came from Merauke. Both of us practiced in Manokwari for one year. The HPB at that time was Mr. H.W. Assink, an Indo (Eurasian). The controleur seconded to him was Mr. du Buy, and the aspirant controleur was Mr. Jan Thooft. After one year of practice, we returned to OSIBA and followed a much broader curriculum than that of the first two years. Dutch language instruction was still given and combined with criminal law, constitutional law, hygiene, and first aid, ethnology, adat law, agricultural economics, administration, civil law, arithmetic, history and geography. That was the final curriculum used for the final exams of 1958.

As mentioned above, I did my practice in Manokwari. Practice was divided into three-month segments. First I worked at the office of the $\mathrm{HPB}$, then I was transferred to agriculture, then I was transferred again to the police, and finally, I returned once more to the HPB's office. So every three months I shifted practice locations. Twelve months were divided into threes, so I shifted practice locations four times. With the police I learned to write warrants and how to process police reports. While in agriculture I learned about nursery seedlings, how to plant and care for them until they were harvested.

As people who worked in government we had to learn all of that because later on, when we became administrators, we would be sure to encounter these things in the field. While we were at OSIBA we also practiced in the village or kampung of Harapan (Sentani), then called Kota Nika (see map of Hollandia). The schools of agriculture, animal husbandry, and forestry were there. We also went to Genyem to see how people dried cocoa beans. This was because the government that was preparing us with the OSIBA education thought that we should know a little about a lot of things for our future work in the field. What served as our working language was Dutch along with broken Malay. The Dutch themselves had a hard time speaking Malay.

During practice I was also tested. When I returned from a patrol, I would hear a report by the HPB about whether Alex was diligent or not. For example, I would be instructed to patrol or make a tour of the 
Kebar plain. Or I would have to go with Dr. Franken or the assistant controller, Mr. Jan Thooft. After I returned from the patrol, I had to make a report on what I had found on the trip, what activities I had done, how I had helped the HPB or the doctor, and who I patrolled with. The report was initialed by the HPB and forwarded to the Dienst van Binnenlandse Zaken (Department of Home Affairs). So it was left up to us to decide; we could just make a brief report. Some of us were asked to do registration here, and various jobs within the administration there. I think their intention was to assess whether I understood and could perform the assigned work or not. For example, I was instructed to make records of people who were ill and had to go to the doctor for checkups. Or I would be told to look for coolies to work on a road, to see how I managed it. Although the tasks assigned were hard, since I was just an average student, they already treated me as an administrator. At the time they addressed me as 'Tuan Bestir muda' or young Mister Administrator. That is how it went.

\section{STUDENTS WHO LIKE TO GET DRUNK GET SACKED}

In the course of practice, our performance was also analysed. And to that end, reports were made so that when we returned to school, the director would also know how we had fared. Oh, this student has returned from practice with good results. Or some students had been mischievous, not worked, not come into the office, or perhaps, got drunk and hung over $(f l y-f l y)$ because they loved to party. This happened, to the point that two of my school chums had to be thrown out of school and sent home. They just did not do good work in the practice. Out of 50 students, the two of them were kicked out of school.

I saw that approaches were being made to the missionaries, who were there before the Dutch government, which had only started up its activities upon the establishment of the first residency by Mr. van Eechoud in 1949. The government had begun forming village councils, so that the problems that occurred in the villages could be resolved there. The government did not start with anything modern. As for the judiciary, the government established a landsrechter (district lawyer) and Landschapsrechtbank (Regional Court). For the south, an alleensprekende rechter (single judge) was established. 
The people involved in the judiciary team were adat leaders and religious figures, just as I had seen in Manokwari, where the HPB was the chairman, and the members consisted of the tribal chiefs in Manokwari. A tribal chief there was, like an ondoafi (adat leader), someone considered to have a good command of adat law and be a good speaker. For example, someone who could tell people that there were practices that, according to adat, should be organized this way or that way. An ondoafi could do this too, although he would only speak at court because of his position. But someone else who understood, or was perhaps a witness who had heard or experienced something himself, could also be asked to speak. At the time I was working in the south, in the Merauke area. The tribes that inhabited the Merauke area were the Marind, the Muyu, the Mandobo, the Djair and the Awyu, as well as the Asmat and others. The judiciary used there then was the single judge. HPB Willem van der Veen served as chairman and investigated the cases, and I served as the recording court clerk. So there were only two people. This was different than in the north, where representatives of the village and community leaders were involved.

\section{BECOMING A DISTRICT HEAD}

After graduating from OSIBA I was placed in Digul. My position then was ter beschikking, that is, I was seconded directly to the HPB. After one year I was appointed district head. I was very pleased by that. It happened so quickly. After I became district head I was appointed (head of exploration of the Eastern Mountains and the Black Valley, or Zwartvallei). As time passed I saw progress, each time I was appointed to replace Dutch officers such as Mr. J.N. van Luyk in Mappi, Mr. Th. L.F. Laumans in Tanah Merah and Mr. J.M.A. Born in Oksibil, Mr. Laumans was a rich man's son, his everyday clothes were always fine, never dirty. I knew for sure that his folks were wealthy. He told us that at his home there were five cars. The speed of the promotions I got were not part of the Papuanization programme, which only began in 1961. The reason for the promotions was really that the government was taking notice, perhaps because I paid attention to my superiors' instructions, understood, and was willing to work. That is how they showed me I was appreciated. 
In performing my job as a civil servant I was very attentive to adat and customs. I had been taught by Dr. Galis how to approach the population. In his view, if you wanted to be an administrator, you had first to master the procedures and habits of the local inhabitants. So that whatever decisions you wanted to hand down would be accepted by the community. They would not just receive orders and then carry them out. You had to first observe and have a lot of patience. You had to observe whether the women should be gathered together with the men or not because in remote areas such as Mandobo or Djair, only the men could be gathered up for work there. The women were away in the field huts. This had to be discovered and sorted out.

Years ago, in a seminar on 'Operasi Koteka' (operation penis gourd) given by Governor Acub Zainal, I asked: 'Why didn't the Dutch rush to give people here clothes?' It was not a job that could be done in a day, but would take many years. Aside from giving them clothes to replace their penis gourds, they would also have to provide good housing, soap, and other things. The Dutch did not do that then because the population itself was not ready for it. Governor Acub Zainal thought it was possible for a single 'operation' like that to succeed, but ultimately it did not. Anyone who knows ethnology knows that such an operation could not be enforced in that way.

\section{EXPERIENCE WITH DUTCH PEOPLE}

In doing my job as a civil servant I worked together with several Dutch people. First with Mr. F.H. Peters. He was the first HPB I ever met. It was hard for the man to laugh; he was stern and stiff. Not long after that came Mr. Anthon Fanoy. He was the second HPB in Digul. I felt very in tune with him. To this day we still send each other letters. Lots of people got along well with him. In Tanah Merah all the people got along well with him because he had done the rounds in the north before that. He had worked in Arso, Waris, Waren, and Wasior.

Everywhere he went in the remote areas he liked to get together with other people. For instance, on Saturday nights he would invite us all to get together at the canteen. There were a few dances there. So I felt his approach was very good, even though he was an ex-army man. If I am not mistaken, he held the rank of captain in the war in Korea. That was 
according to him, but he was actually born in North Sumatra. His father was an administrator, too. That was how his story went. He was born or raised there, so apparently he already knew how to manage the area and the people.

I saw that when we were working on something, he himself always lent a hand. Even though he was the HPB, when we wanted to make a soccer field, it was he who handled the tractor. Ha-ha-ha ... he was great! Or there was the time we were working on the main road of Arimob; he was the one who bulldozed it. Also, if there was no one to steer the boat, he was the one who did it. This was because, according to him, he was an engineer who knew all about machines. That was what he said. And he told me that he had fought in Korea. A lot of Dutch people were sent there too. There were administrative officers who had taken part in the war in Korea for a year, then sent to perform duty here.

So I personally got along well with them, there was nothing hard about that because at the time almost everyone was a bachelor. So everything was fine, there were no hassles. As for HPB F.H. Peters he already had a family, but HPB Anthon Fanoy was still single. For me, the atmosphere back then was very fine, because all of us were still young. And he always directed us. I got concrete examples and instruction from him, he was always giving us guidance about how to solve a problem. Sometimes he called us to his house to tell stories. I see that as proof of a good relationship because until now we have stayed in contact. And whenever he misses me he says he hopes that sometime I will visit him over there.

In the Netherlands New Guinea government period I served solely in the interior. So I worked first in Oksibil, then in Boven Digul, Mappi, again in Oksibil and in Bokondini in the Baliem valley. Then the transition happened. After that I was transferred to Waighete on Lake Paniai, then from Paniai I was transferred to Jayapura. Actually, the approaches that were used by the government in the interior were good, except that of Mr. Golsalvez. I have read that book about all the fuss that got stirred up because Mr. Golsalvez had killed a Dani in the Baliem Valley. But I think he had already been examined by the prosecution at the time.

Based on my experience, at that time it was really hard to resolve a case in the community. For example, there was a criminal, but it was hard to find the culprit. Sometimes a decision was made to just shoot. But sometimes an effort was made to catch the perpetrator in order to find out the exact motive. Only when he was arrested could his followers sur- 
render. In the interior, I did not see anything to fault our Dutch friends because I saw that the patrols were passing all the time. If I went on patrol with Mr. Raphael den Haan, I really learned my lesson! The man walked on and on! They tried to get to know the whole work area with precision. And what I enjoyed most about them was that if they found a disease in a place, they gave a warning and immediately asked the health department to come to provide health services. That is what I saw.

Formerly, when campaigns to eradicate diseases were carried out, everything went very smoothly. The biggest one was the eradication of malaria. A tuberculosis eradication campaign was also carried out by Dr. Muller, who was very famous here. He slept overnight among the residents in Lake Sentani. He carried mobile lung x-ray equipment so he could directly examine the people in Sentani. The residents of Lake Sentani were very familiar with him. That is what I saw here. Dr. Muller has since died.

Formerly, there really was a bit of a difference between us and our friends who worked in the city. For example, what I heard about from my friend Boekorsjom. He did not agree when Dutch people paid more attention to the Ambonese than the Papuans. Because it was like this, whoever was first to be able to speak a little Dutch, he would be close to the Dutch. That is what my friends saw at times. But during the time I worked there, since I happened to speak a bit of Dutch myself, I was also included in the group that was close to the Dutch people. There were character differences between the Dutch who worked in the cities and those in the hinterland. Take Mr. Anthon Fanoy. When he ate, he mingled with other people. Not using a tablecloth was okay. And he was not picky about eating. He was even willing to eat taro. But in town, yes, the (local) guests would wait for the foreign host to eat first. And usually local people saw that as something that might not be good. Although that was how it was supposed to be. If you wanted to talk, you had to wait because people were eating. So sometimes there were things like that.

On the other hand, if you went up to the political level, yes, it was possible to speak up, or to speak out of turn, because sometimes people could not agree (with the development approach of the Dutch). For example, in talking about independence, they felt it was not necessary for everything to be settled beforehand. Rather, they might say, let us have freedom first, and only after that, development will follow. As Bung 
Karno once said: 'If you want to marry you don't have to prepare the furniture first, just get married first.'

\section{OFFICE ETIQUETTE}

There was no such thing as a relaxed or informal atmosphere on the job. Because under formal circumstances, I could not just enter the work space of the HPB, since he was the boss. If I wanted to report something to the HPB, I could not just go in as I pleased. I could only meet the HPB at a time he determined. So he really stuck to the formal procedures. I understood that since we had already been educated about that at school. We had to remember well, formal relationships were like this, informal relationships like that. So we already knew about that.

Let me give you another example. If I wanted to use an official boat on a Sunday, I had to arrange for it beforehand. I could not just suddenly come and borrow a car to go to Digul to hunt pigs. It could not be done that way; I had to ask the day before at the office.

If we wanted to use official property, we had to discuss it beforehand during office hours. That was always emphasized, so we knew. For another example, if I came before the HPB, I was allowed to sit when he told me to sit. So one could not sit down first before being told to do so. Ah, those were the rules. 'You have to wait, Alex, don't sit down before you are told.' Ha-ha-ha! However, in Merauke I observed a well-known HPB who was different from the others. Almost everyone was allowed to enter his house. Whether they were natives of Merauke or anyone at all, they could come in. When someone came to his house, he would call to his wife: 'Mama, this person wants to eat. Please eat.' That surprised me!

If people came asking him for money, for example, one guilder or 50 cents, he would give it to them. But eventually he got a reprimand for this. Where did Van der Veen get that money, which he just gave out to people? Or if people came to him asking for cigarettes, he gave them cigarettes. Or people came looking for cigarettes, and he gave them a voucher to pick up cigarettes at the store. He was different from the others. I sat there thinking: what kind of approach is this? From one village to another, everyone supported him. And if he told the people about work on a road, everyone wanted to work! Because after they finished working on the road, he said, 'Now let's have a party!' 
Most of the HPBs were trained in Indologie (Netherlands-Indies Studies), before coming here. And most of them came from the island of Java. And it was probably there that they had learned that they might succeed better with that kind of approach [engaging both formally and informally with their staff]. So HPB Willem van der Veen just wanted to party. Ha-ha-ha! ... But if people wanted to make mischief he would beat them with rattan cane to serve as an example to others. So sometimes when I reminisce, oh ... it is so funny!

Everyone liked him. After Merauke he was transferred to Serui. I heard similar stories in Serui. In Serui to this day people still remember HPB van der Veen. But HPB J. du Bois was another story. Ooh, he was so tough, just could not laugh, and you could not get close to him. But it all depended on their personalities. So we did not blame anyone. If that was the man's nature, we just had to accept it.

\section{COWRIE SHELL FINES}

What I loved most about the interior was making patrols. I was happier doing that because I could talk directly with the people. When we were at the government post, it was hard for us to meet them and we rarely talked to them--except if they were invited to the post to work on something or to get some information or an order, then they might come. But if not, they stayed put in their villages. If a case arose, they came to report it. And it was preferable if, when a problem occurred, we came in and managed to resolve it; then they were delighted. The people in the hinterlands had a thousand different kinds of complaints. One moment one said this, later one said that. One reported this, one reported that. Oh, there were so many. So we had to be very patient with them.

But the patrol time was usually brief, so there were problems that could not be settled right away. Take a recent example from Waighete. There are three districts there: Tigi, Kamu or Moanemani, and Mapia. On the coast is Nabire district. Now it has become a kabupaten. Over there, when they wanted, for example, to bring a woman (involved with a case) to the government post, it was rather difficult. First of all, she was shy and if she had to be forced, then they tied her up. Usually the request was made for the administrator to just come to the village, provided the problem was concentrated in a certain place. For example, if there was a 
problem between two villages, that meant that a neutral village had to be chosen. Where they could be taken to settle the dispute with them. If a man's wife was raped, her husband would feel ashamed if the case were dealt with in his own village. In such a case a fine was usually paid. In the old days, a husband had to respond by taking a wife from the other person. But in the long run they were just fined in cowrie shells.

So over there, in settling cases, one case took three or four days. It could not be settled in one day. They sat and talked for a whole day. In Paniai an adat leader was called tonawi, equivalent to bobot (in Ayamaru). When he spoke, it was for two to three hours. If the culprit was forced to confess, oh, it was hard. In a regular court or police interrogation - I think this was also true in the Netherlands - a woman was usually interrogated by a woman. But there, if a man was doing the interrogation, the woman would be more likely to keep her mouth shut. If she refused to speak, she was beaten, threatened. The more so if she knew that later, if she confessed, she would be inviting trouble. So the person running the investigation had to have a lot of patience. Because of that I liked patrolling in the interior.

The HPB usually gave us permission to patrol and investigate cases. He said: 'Go now, and if a case is tried, just bring the summary to the HPB office. If people do not want their case to be settled, just make a deposition and bring it back to the HPB office. But if they agree, settle it there and tell them to reconcile as proof that the problem has been resolved.'

\section{THE ISSUE OF WOMEN AND PIGS}

The most frequent violations to occur in the interior were related to the issue of women and pigs. On patrol we also saw the situations of the villages. Before setting out on a patrol, we got instructions about what to look out for. At times there were incoming reports about the situation in the patrol area, for example, a report that there was a teacher who was not teaching properly, and so on. So we already had an idea of the things we might face. We were to check on the truth of the matter in the field and if we could not resolve the situation, we brought it back to the office of HPB. Often, one problem was associated with other problems. 
The HPB was always giving instructions because a report had been brought in earlier by the village head, or villagers, or by people who were conducting research. If they found things that called for attention from the government, they would immediately inform us. If we compare this to the Indonesian period today, everything at that time was done quickly.

The period that the United Nations Temporary Executive Authority (UNTEA) was in charge was so brief that I could not expect much from them - their terms of service lasted only a few months. Let us take the example of a natural disaster, such as happened in Wamena. I no longer remember what big natural disasters happened in the Dutch period. But when a natural disaster struck, all operations were handled by government agencies, such as the Social Department. They went right down to deal with it. So there was no need to form committees like they do today. The HPB or resident reported the natural disaster to the head of the central government in Hollandia, and the government directly intervened. But today, Wamena is screaming for help, but no agency is acting yet because they have to wait for a committee to be established first. That is the difference I see between then and now.

Formerly, money was scarce, but the frequency of the field patrols was remarkable. Now there is a lot of money, but I see that the former results were better than they are now. Now, for example, even the camat (sub-district heads) get tactical funds. Today's camat control a lot of money. Before, when I was a camat, I received nothing at all. What I mean is this. Formerly, you would only receive money when you were going to take action, but the camat today receive money even before they do anything. Camat today ought to be anticipating action as soon as they receive tactical funds. The advantages of that way of working back then, with its great results, were not achieved just like that. Before reporting to the HPB, we discussed and inventoried all the problems found in the villages during our patrols, we organized it all into reports, then reported to the $\mathrm{HPB}$, and he forwarded the reports to the resident.

And the resident would see which issues were within the scope of his authority to handle, and which had to be passed on to the governor. After checking them, the governor would say: 'Ah, this is not within my authority, it should be sent to the minister van overzeese rijksdelen (minister of overseas territories. It pleased me to see this way of working because everything was clear. Formerly, all the government agencies, including the police, were coordinated by administrators. That is also why all those 
subjects were taught at OSIBA, so we would learn and know them. Things like matters of agriculture-- even though we were not agricultural engineers, we learned about agriculture, too.

\section{THE UNTEA PERIOD}

I went through difficulties when the UNTEA left. The UNTEA period was only a transitional government period. Because they were only there momentarily, they just followed the existing patterns. So they did not interfere with anything (the positions) in place. But after the transfer to the government of Indonesia, everything had to be adjusted to conform with the Indonesian regulations, and there we went through great difficulties. At that time I was still in the interior, in Waighete. After Bokondini I was transferred to Waighete. The UNTEA resident working in Bokondini was called Mr. Carter; he was a New Zealander. There was also an Englishman who came from Borneo (Kalimantan); he spoke Malay fairly well. They never talked about anything more than the things that concerned them, such as whether or not there was food in the government storehouses for the people or for the government employees there, so they did not leave the post. That is all they noticed. They did not give much attention to other kinds of work.

The patrols were stopped. Since no funds were provided for them, they stopped. Since there were no patrols, we did not report anything, so they did not receive any information, either. For example, I once reported that there was someone from Pas Valley who had come in and was disturbing people there. But Mr. Carter said: 'Ah, that's a matter for Wamena, and not Bokindini.' He did not give a damn. I understood because they had already said that they were only working there momentarily. But my experience when UNTEA exited was a little bitter. Alas, in Jayapura affairs were very different. People who had previously held no position were given positions. And people who had been promoted through the ranks were no longer employed. Everything was dominated by the pro-Indonesia people. That is where we ran into difficulties.

Suddenly we heard the news about who would be leaving for Java to go to school. But what diplomas would those going need to have? In those days, the highest levels of education here were offered by the PMS, MULO and HBS (junior and senior high schools), but only very 
few Papuans were attending those schools. There was the Kweekschool (training college for teachers), which had only run for six months before the transfer period took place. Even though people had no diplomas, they were sent to academies here and there anyway. Let me give you an example: My friend who replaced me in Bokondini was sent to attend a Cadre C Course (KDC) in Bandung. What surprised me was that he left for the KDC, but based on what diploma? Whoever was seen to have a good attitude toward the Indonesian government, he was welcome, he was given the chance!

At that time, people began to be discriminated against. So it was understandable why Pattipi could enter the Akademi Pemerintahan Dalam Negeri (APDN, Academy for Domestic Government) in Malang - Pattipi, who later became governor - because he said he was a partisan (red and white). He, my very own friend, was an example. And the rest of us were not given the chance. Only when they said, you are promoted, were you promoted. But if not, right, you just stayed as you were. I could not get a promotion from class C3 to class D2. It came to a standstill. I actually experienced this personally. I started working and collapsed there. Completely went to the dogs! And there was no other way open to me. I wanted to enter the Dewan Musyawarah Pemilihan (DMP, Election Consultative Council) but could not do that either. Because they already knew a lot of stories about West Papua, they said we were too influenced by the Dutch. The stories sometimes strongly implicated us personally. The ones who suffered the most were me and Faidiban, because around 1969 we were put in detention; the same happened to Boray.

I mean, they might have invited us to vote, but they did not want to because they already knew who was pro and who was against. It had been monitored, because their spies already knew. So careers were like that too. The scores on our conduitestaat (employee records of good conduct and work performance) sometimes did not reach 80. If a score of 87 was required, you might get in, but if your score was only 70, you could not. But because the civil servants loved their jobs, they just stayed the way they were. No problem, I thought. Serving as the head of local government (kepala pemerintah setempat or KPS, the Indonesian translation of the Dutch HPB title) posed no problem, nor did serving as staff because it was so evident. The fact that there was discrimination - that was where the big difficulties lay. And that was what made the people of Papua fragmented. 
If they had seen us as people who were diligent and faithful about working in the interior, they would have understood how I could become district head in one year. That was how it really was, anyway. All the same, if the Dutch and the Indonesians assessed the same man, their assessment would be sure to differ. In my opinion, the Dutch and the Indonesians, equally, conducted objective assessments, but the difference was that the Indonesians' assessments depended a lot on whether they were pleased with you or not. Previously, when I was scolded by the HPB, it would not impact on my career. Moreover, if I defended the truth, the HPB would actually accept my reasons.

We strongly felt the consequences of the UNTEA pulling out. Whereas in fact, according to the New York Agreement of 15 August 1962, the UNTEA should have assisted us until 1969. But it was clear that after the UNTEA withdrew as of May 1963, everything was going to be difficult for us. At the time I was serving in Waighete.

THE IMPLEMENTATION OF THE ACT OF FREE CHOICE IN WAIGHETE

It happened like this. I still remember it well and two of my employees, who just recently attended the congress, ${ }^{1}$ also witnessed it. At the time, the government wanted to gather people in Waighete, but I, as the KPS of Waighete, was ordered to organize a patrol to the southern area of Mapia to conduct a population census. I thought: 'Oh, this cannot be, because this is part of the Etna Bay area.' But I heard from an Indonesian friend of mine that the government did not want me to be at the meeting held by the government with the people in Waighete. Because it was an order, I had to leave. Alright then, no matter. I left that day, and the next day those organizing the vote arrived in Waighete.

The reason I was ordered to make an official trip to South Mapia was to ensure I would not be able to attend and witness the meeting to be held Waighete. As I said at the congress recently, I did not know what they discussed and decided at the meeting Waighete. After I left, they talked and made grandiose promises, that later on they would send

\footnotetext{
The reference here is to the Kongres Pelurusan Sejarah or the 2nd Papuan People's Congress held in Jayapura 2000, in which Wamafma, Boray and Faidban were all very involved at the time the interviews for this book were conducted.
} 
airplanes carrying all sorts of goods, provided that all the people were willing to go down to cast their votes with the Dewan Musyawarah Pemilihan (DMP, Election Consultative Council) in Nabire.

I could not attend. The same was true for other friends, because they already knew who was for and against them. What's more, concentrating it in Nabire meant that people who lived in the Paniai highland area could not attend. As for the people who were brought there, many were illiterate, and easy to persuade. All of these events were recounted at the congress the other day. Someone recalled receiving a small batteryrun, Gründigbrand transistor radio, a flashlight and battery and a little money. Ah, that is all.

In Wamena, the way it happened was different. They were coached from 1968 to 1969; then the selected members of the Election Consultative Council were dispatched to Jakarta. On arriving in Jakarta they were lulled in all kinds of ways. After they returned, they said to the people: 'Yes, we are just joining Indonesia!' In other areas it was almost the same. The other day they all described their experiences as members of the Election Consultative Council, or DMP, including Theys Eluay. He said: 'I was picked up from my home and taken to Dok VIII. When I arrived there the place was nice. I slept there, but was not allowed to go anywhere. Parcels were provided, to be brought home later as gifts, after the statement was signed (saying that Irian Barat would remain in the Republic of Indonesia).' This happened everywhere, with the same pattern.

The other day most of them were present on the congress panel, which was meant to include all the people concerned at the time. That was why the number of panel members was increased from 200 to 501. The congress presidium had said: 'These people are all included on the panel so they can relate their experiences (in the DMP). And later if there is another dialogue, they will speak as witnesses.' Yesterday those who talked were both women and men, and everything they said was in the same vein. I also heard that Ortis Sanz has Parkinson's disease, but he still remembers all the events.

\section{DETAINED IN IFAR GUNUNG}

After I returned from South Mapia when the implementation of the Act of Free Choice was over, I was supposed to move to Sorong, but that was 
a dead end due to the destruction of the airfield. In Wisselmeren (Paniai) an uprising occurred on 1 May 1969. Finally, I could neither go forward nor backward, neither to the left nor the right. No matter what I did, I would still be a victim. I, wearing shorts, and my wife, in a house dress, went to meet Mr. Cato from CAMA. He brought and handed us over to the regional military command (Kodam) in Sukarnopura (Jayapura) and we were kept there.

I did not leave for Sorong, because they said that if I went to Sorong, I would be arrested later. They wanted to arrest me in Waighete, but I escaped. It would have been very dangerous if they had arrested me because in those times, if someone went missing, there was no need to look for him. So it really was very inhumane. If they just wanted to ask us questions, we could answer. But if there were strong suspicions that the person was one of the masterminds or had spoken against the government, yes, it was hard. Because we really could not speak freely and defend ourselves. For example, once I flew from Sukarnopura to Wamena. I had a small metal Papuan flag pinned on my shirt.

Abner Mokay from the police said to me: 'Oh, Bapak KPS, how can you be like this?' It was quite reactionary. I said: It's just a shirt button!' But they were already set. They wanted to eradicate any resistance so the implementation of the Election Consultative Council would run smoothly.

I surrendered in Sukarnopura, as that was how things had been arranged. I was immediately handed over to Sarwo Edhi Wibowo, the regional military commander at the time. Sarwo Edhi Wibowo has since died. He said to me: 'Now you are being detained so your information about the Waighete uprising incident in Paniai on 1 May 1969 can be heard.' I was separated from my wife, who happened to be pregnant with our last child at the time. While I was in detention, I was moved for a while to the detention centre in Ifar Gunung. At times I was held together with Herman Wajoi and Lukas Rumkorem, but in separate cells.

When they knew a prisoner was cheeky and smart-mouthed, he was moved to another place. That way he would be completely blocked, to ensure there was no talking contact between political prisoners. If a prisoner was suspected of this, he ate in his cell and was not allowed out to mix with the other prisoners even though there was no real danger in it. First I was held in Dok V, after that I was moved to Kodam, and from there I was transferred again to Ifar Gunung. 
I was afraid of being imprisoned in Ifar Gunung, because there were political prisoners who had disappeared there. So I always said to Bapak Hartono, who was Catholic and the commander of the detention centre: 'Bapak, don't mix me up with other prisoners, because my problem is different.' I hoped they wouldn't get rid of me!

The ones they got rid of were people who they considered politically dangerous. If you spoke too loudly or talked about things that were antiIndonesia, they would say: 'Oh, this person has to be eliminated! And many people were eliminated in Ifar Gunung, including some of my former OSIBA friends, such as Penehas Torey and Ibo. They disappeared without a trace, and even now people do not know where they are. If a prisoner was taken away at night, people did not know their fates. Our situation began to lighten up on 2 August 1969 when it was announced that Indonesia had won the Act of Free Choice.

\section{AMNESTY}

I was imprisoned in 1969 and released at the end of 1970. I was arrested during the time the Act of Free Choice was taking place in the middle of 1969. And after I was set free, I was directly sent to the APDN. Yes, they said that there would be a refresher course there, so we could love the Motherland again. I was at the APDN in Yoka from 1970 to 1973. As for Faidiban and Boray, they studied earlier on at the APDN in Malang. Dorus Rumbiak, the former bupati of Biak, and a lot of the other old administrators also took the course together with me. We attended studies at the APDN from 1970 to 1973.

After graduating from the APDN I returned to work as usual because I was given amnesty. At the time we were summoned before the regional military commander, and he said that the Act of Free Choice was over and the president had given pardons (amnesty) to all the tapol and napol (political prisoners and detainees).

If I am not mistaken, everyone was given amnesty. But I do not exactly know because it could be that those involved in armed conflict did not get amnesty. Like what finally happened with Eliezer Awom, who was imprisoned at the Kalisosok Surabaya correctional institute. Eliezer Awom had been involved in armed conflict and was sentenced to life imprisonment, but in 2000 he was given amnesty by President Gus Dur. 
After graduating from the APDN I returned to work in government. And in 1980 I became the first camat in South Jayapura. They said I was good, healthy, and able to work again. So it was that I continued to work and ended up serving as the head of the Biro Lingkungan Hidup (Environment Bureau), and after that I retired.

Finally, I was asked to take part in the panel at the congress. I was asked by friends. Indonesia was not likely to grant permission. Those of us who were given amnesty had to be very cautious at times. Others, like Theys Eluay and Thom Beanal did not. Theys was pro-Indonesia back then, one of the red and whites. Thom was not, but perhaps he was neutral. At the time he was a teacher at some place in the Mapi area in Waighete. That is what I know. 